\title{
Women's Voices
}

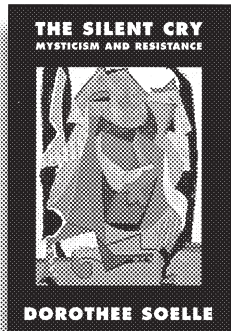

DOROTHEE SOELLE

THE SILENT CRY

Mysticism and Resistance

Soelle gives theological clarity and direction to the mystical impulses of contemporary seekers by tracking the sites of mystical experience in nature, sex, pain, community, and joy.

0-8006-3266-4 320 pp paper $\$ 20.00$ (\$30.00 in Canada)

\section{SALLIE MCFAGUE}

\section{LIFE ABUNDANT}

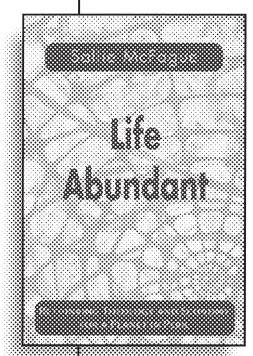

Rethinking Theology and Economy for a Planet in Peril

McFague encourages and models a theological practice that "gives glory to God by loving the world."

0-8006-3269-9 272 pp paper $\$ 18.00$ (\$27.00 in Canada)

JEANNE STEVENSON-MOESSNER, Editor

\section{IN HER OWN TIME}

Women and Developmental Issues in Pastoral Care

Takes a probing theological and psychological look at the possibilities and hurdles in the life-span of today's women.

0-8006-3137-4 408 pp paper \$21.00 (\$31.50 in Canada)

\section{SERENE JONES}

\section{FEMINIST THEORY AND CHRISTIAN THEOLOGY}

\section{Cartographies of Grace}

Brings feminist theory into fruitful conversation with Christian theology in the contexts of human identity and gender.

0-8006-2694-X 216 pp paper $\$ 17.00$ ( $\$ 25.50$ in Canada)

REBECCA S. CHOPP and SHEILA GREEVE DAVANEY, Editors

\section{HORIZONS IN FEMINIST THEOLOGY}

\section{Identity, Tradition, and Norms}

A new generation of feminist theologians rethink the central claims of feminist theology and offer proposals for the future.

0-8006-2996-5 $272 \mathrm{pp}$ paper $\$ 21.00$ (\$31.50 in Canada)

\section{SHARON D. WELCH}

\section{A FEMINIST ETHIC OF RISK}

Revised Edition

This influential feminist text, now updated, proposes a new model for ethics and a new life-orientation for social justice.

"... a provocative and insightful book."

- SAllie McFague

0-8006-3185-4 208 pp paper $\$ 18.00$ ( $\$ 27.00$ in Canada)

At bookstores or call 1-800-328-4648

FORTRESS PRESS

Augsburg Fortress, Publishers

www.fortresspress.com

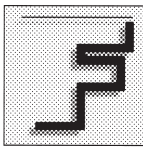




\section{New Women's Studies}
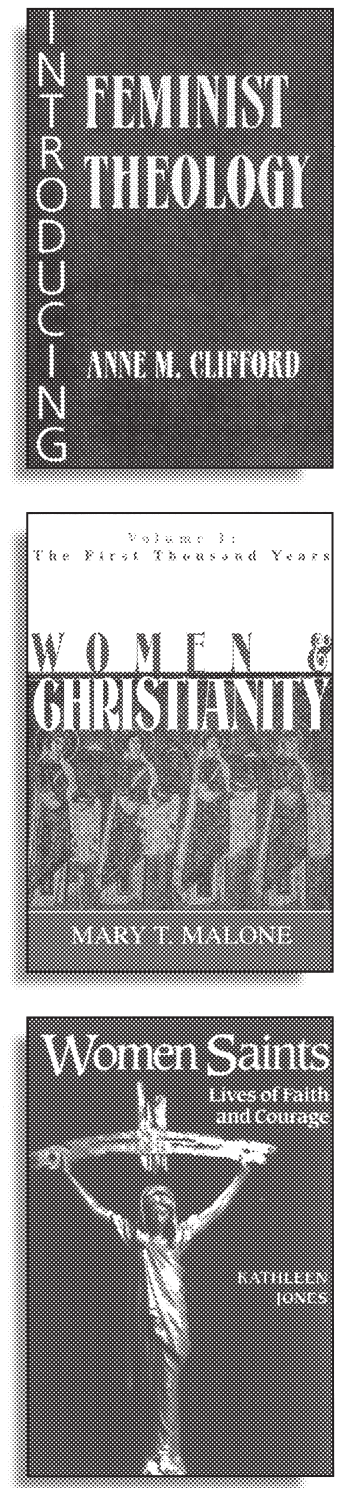

Anne M. Clifford

\section{Introducing}

\section{Feminist Theology}

This superb comprehensive introduction to feminist theology considers the perspectives of women with very diverse life experiences and relationships to God, church, and creation. Each chapter contains questions for reflection and discussion, areas for exploration, and suggested readings.

1-57075-238-9 Paperback \$21.00

Mary T. Malone

\section{Women \& Christianity}

\section{Volume I: The First Thousand Years}

The first volume of a major historical trilogy that documents the lives and achievements of Christian women from the beginnings of Christianity to the present. "Introduces us to a remarkable group of individuals who made history different." - DALE T. IRWIN

1-57075-365-2 Hardcover \$40.00

1-57075-366-0 Paperback \$20.00

Kathleen Jones

\section{Women Saints}

\section{Lives of Faith and Courage}

Original portraits of 40 holy women refresh our understanding of church history and inspires us to lives of courage and devotion.

1-57075-291-5 Illustrated paper \$20.00
A World of Books that Matter www.orbisbooks.com
At your bookseller or direct ORBIS BOOKS Maryknoll, NY 10545 1-800-258-5838 